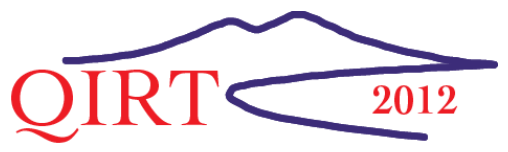

\title{
IR thermography assisted analysis of the textile air diffuser
}

\author{
by V. Burek *, D. Dović *, S. Švaić* \\ ${ }^{*}$ Dep. of Thermal and Process Engineering, University of Zagreb, I. Lučića 5, 10000 Zagreb, Croatia, \\ ddovic@fsb.hr
}

\begin{abstract}
Recording of a thermographic profile for non-isothermal air stream from the textile air diffuser, also termed as a fabric duct, was conducted. The air stream temperature and velocity were measured at different planes and distances from the air diffuser for different flow rates. The air stream thermographic profile was recorded by using a curtain placed perpendicular to the outlet plane of the diffuser. The temperature profiles recorded by IR camera were compared with the results obtained by thermocouples and discussed in the light of the air stream velocity. Also, based on the performed measurement and analysis, the empirical expressions were developed allowing determination of the velocity and temperature within the air stream.
\end{abstract}

\section{Introduction}

Compared to the conventional air outlets, the textile diffusers (figure 1) are characterized by a relatively low velocities and even distribution of delivered air stream. This makes them suitable for supplying larger amounts of air directly to the occupied zone and obtaining by that a large air exchange rates in conditioned room (up to $20 \mathrm{ACH}$ ). Due to the low weight (cca. $300 \mathrm{~g} / \mathrm{m}^{2}$ ) they can be easily mounted and used in various types of room spaces (offices, restaurants, swimming pools, sport and industrial halls). Also, they are washable, do not have corrosion issues and act as a noise silencer. Different types of textile distributors can be found in HVAC systems (figure 1). When the air permeable textile without or with micro perforations $(\phi<1 \mathrm{~mm})$ is used, the outlet velocities of the air are very low $(v<0,2$ $\mathrm{m} / \mathrm{s})$. A higher air flow rates and better induction with surrounding air is achieved with larger perforations $(\phi 5-10 \mathrm{~mm})$.

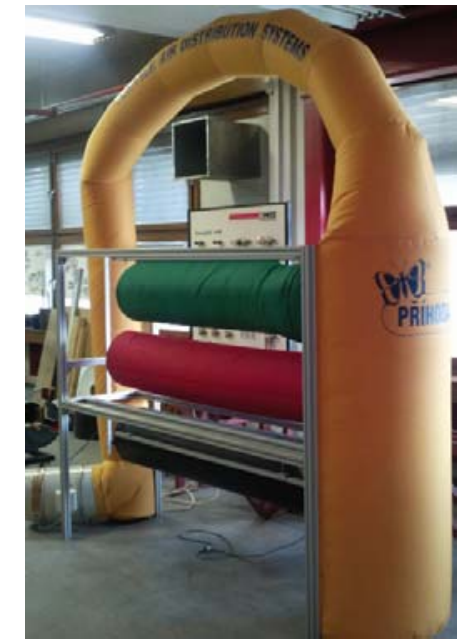

a)

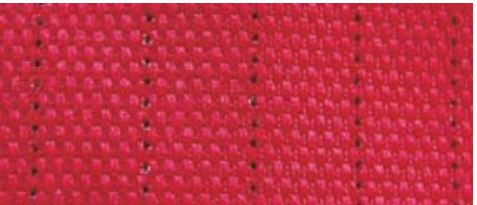

b)

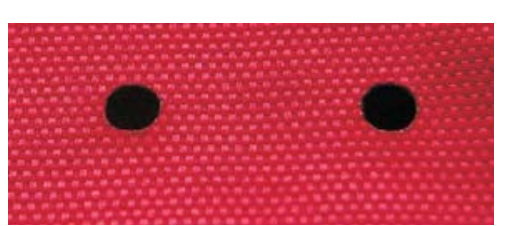

c)

Fig. 1. a) Textile air diffuser, b) duct with micro perforations $(\phi<1 \mathrm{~mm})$,

c) duct with perforations $(\phi=5-10 \mathrm{~mm})$

A rather scarce amount of data on the air stream velocity and temperature distribution is available within the open literature. Some CFD studies [1] indicate more uniform distribution of conditioned air within the room obtained with the textile distributor than with the conventional one, as well as faster heating of the room air.

In order to properly size HVAC system and to achieve desired thermal comfort, it is necessary to have reliable data on air velocity and temperature in a textile distributor air stream. This issue was dealt with in the present work, by using IR thermography along with the standard methods for recording velocity and temperature profiles in the air stream. 


\section{Testing}

The test rig consists of the fan, air heater, air ducts, textile diffuser and curtain of a low conductivity (paper), figure 2. The conducted tests comprise the velocity and temperature measurements in air stream from the textile diffuser with perforations $\phi 10 \mathrm{~mm}$, figure 1c. The measurements were performed at different flow rates with the isothermal and non-isothermal air, in different horizontal and vertical planes and distances from the diffuser. The air velocities were measured by the wire anemometer $(0-10 \mathrm{~m} / \mathrm{s})$, while the temperatures by the thermocouples. The thermocouples were assembled in a grid and fixed on a holder which was moved along the diffuser duct. The all measured quantities were recorded in time in order to obtain averaged values at certain position. IR thermography was applied to record the temperature fields within the air stream by means of a low conductivity material curtain (paper), placed in parallel with the air stream direction, as shown on figure $2 b$.

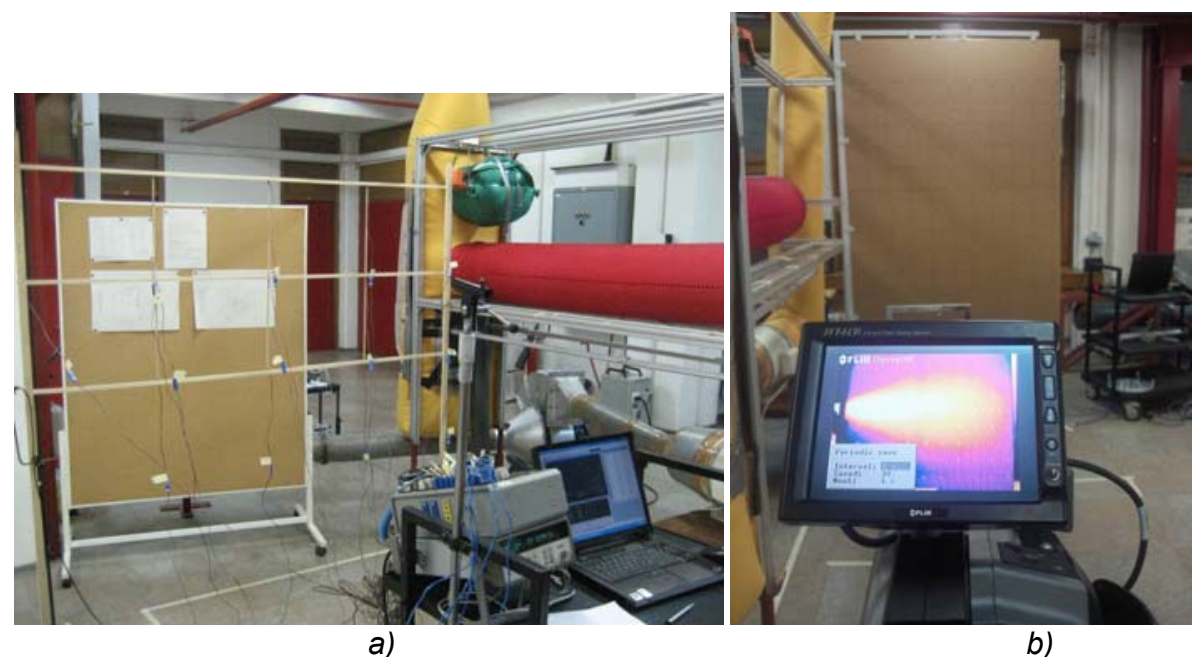

Fig. 2. Test rig, a) thermocouples holder, b) curtain of a low conductivity for IR measurements

\section{Results}

Velocity filed in the horizontal plane including perforations in non-isothermal air at the temperature difference supplied to surrounding air $\Delta t=5.8{ }^{\circ} \mathrm{C}$ is shown on figure 3 . The corresponding temperature field obtained by thermocouples is shown on figure 4.

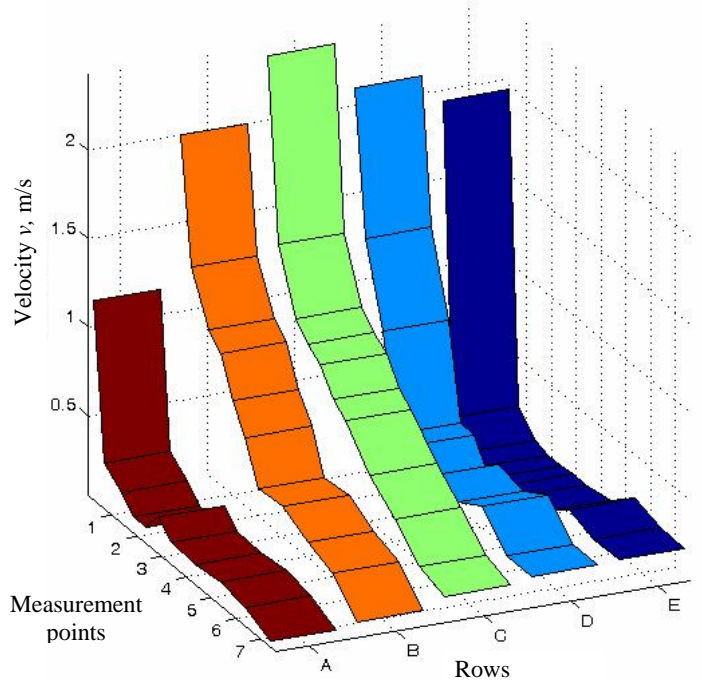

Fig. 3. Velocities at the central horizontal plane (including perforations) at non isothermal volume flow rate $V=470,3 \mathrm{~m}^{3} / \mathrm{h}$ per $1 \mathrm{~m}$ of diffuser length and $\Delta t=5.8^{\circ} \mathrm{C}$ (row $A$ is closest to the air flow entrance to the textile duct, row $D$ is at the opposite side of the duct) 


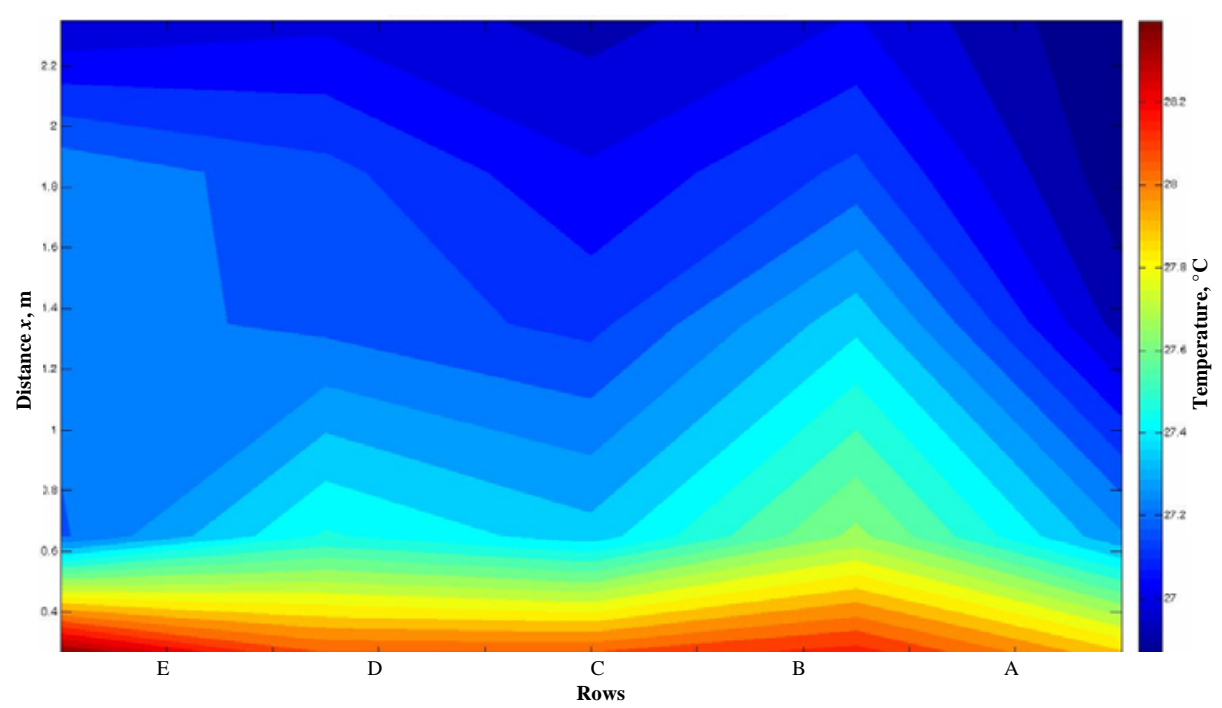

Fig. 4. Temperatures obtained by thermocouples at the central horizontal plane (including perforations) at nonisothermal volume flow rate $\mathrm{V}=470,3 \mathrm{~m}^{3} / \mathrm{h}$ per $1 \mathrm{~m}$ of diffuser length and $\Delta t=5.8{ }^{\circ} \mathrm{C}$

Figure 5 shows comparison between the temperatures recorded by thermocouples and IR camera, in the plane of the curtain at mid position along the diffuser duct. The average temperature difference is about $0,5^{\circ} \mathrm{C}$. Figures $6 \mathrm{a}-\mathrm{e}$ represent the temperature fields of the air stream at different positions on the curtain moved along the diffuser. Distance between the aluminum folia spots visible on thermograms is $5 \mathrm{~cm}$ in the central axis and $10 \mathrm{~cm}$ in other parts. The thermograms were recorded every $2 \mathrm{sec}$ while the steady state is reached up to $100 \mathrm{~s}$ after the curtain was placed in a certain position. Temperature distribution of the textile diffuser with all parts in operation (upper duct with micro perforations and tested lower duct with perforations) is provided on Figure 7. Temperatures in different spots indicated on these thermograms are listed in table 1.

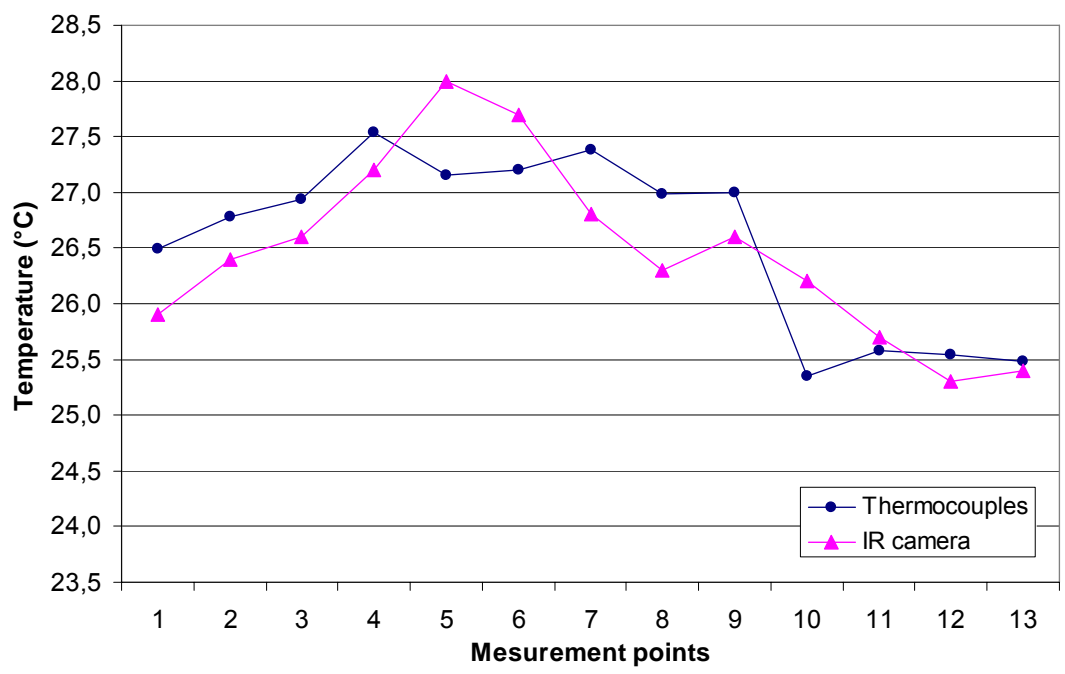

Fig. 5. Comparison of temperatures in air stream obtained by thermocpuples and IR camera (distance between measurement points is $10 \mathrm{~cm}$ ) 


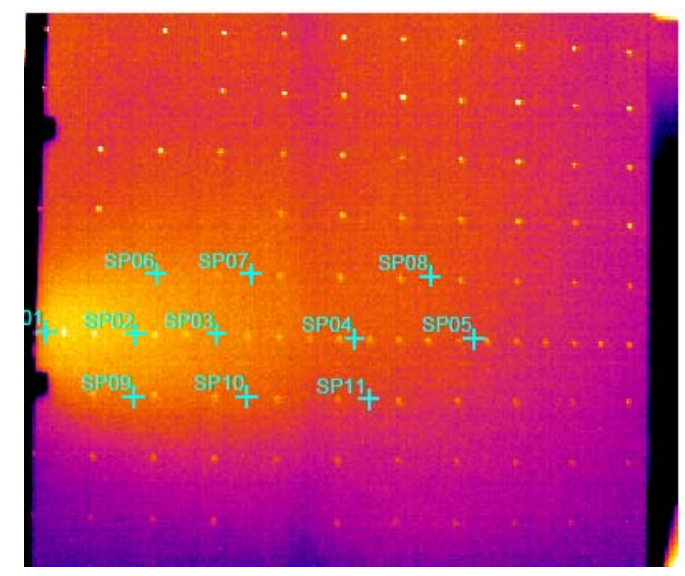

$\operatorname{row} A$

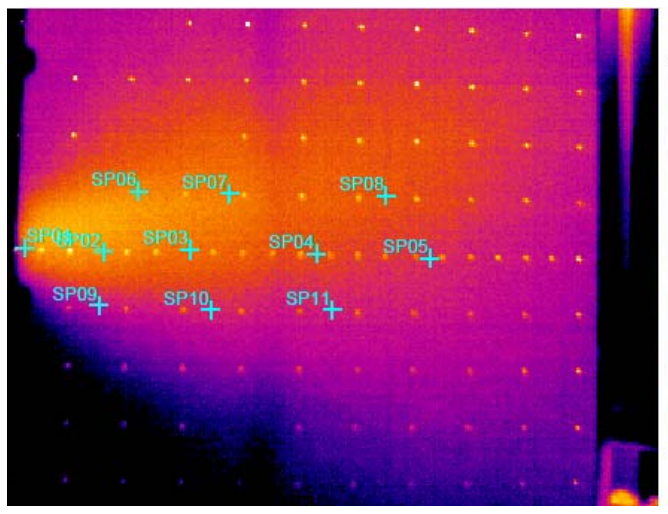

row $C$

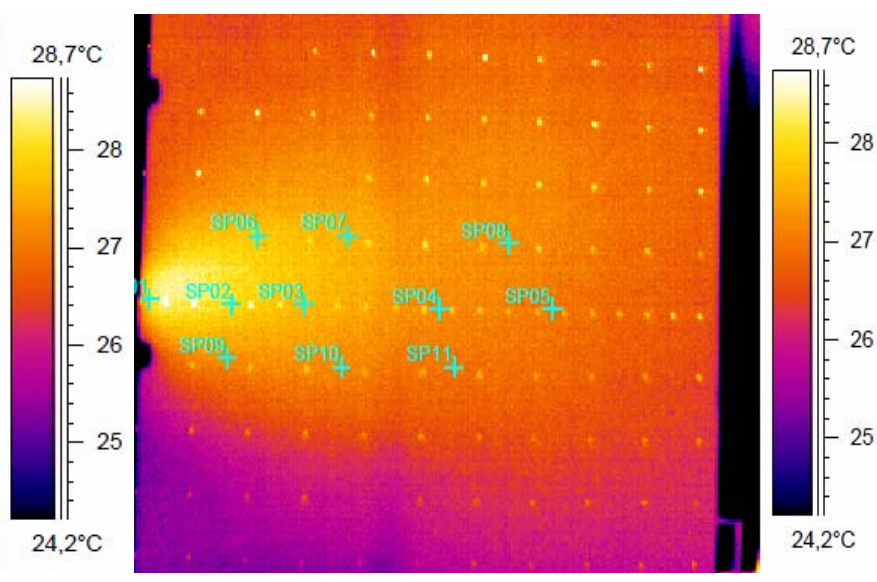

row $B$

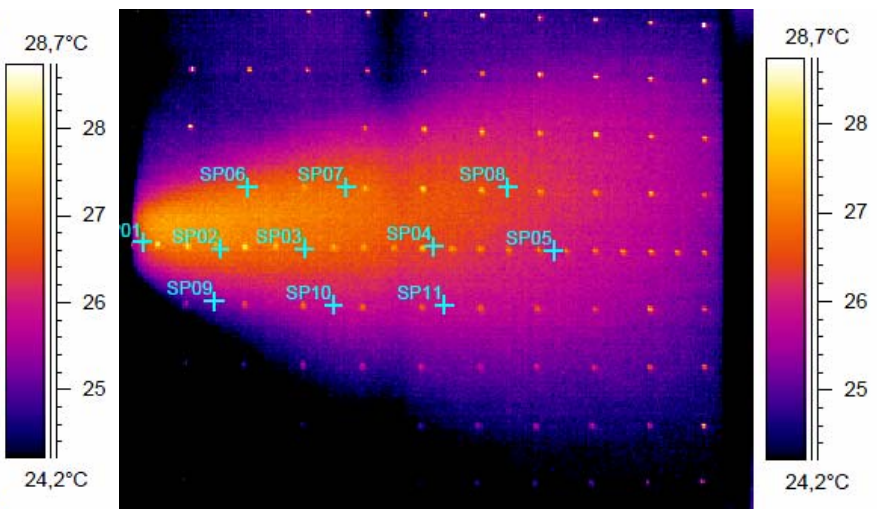

row $D$
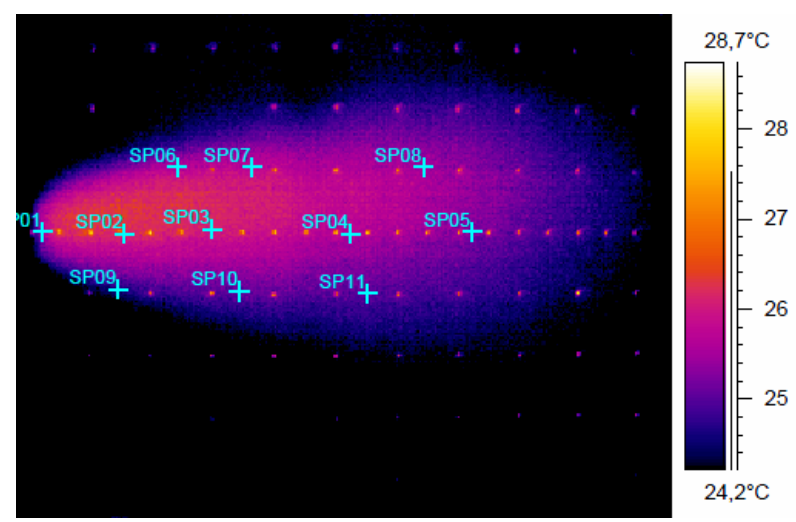

row $E$

Fig. 6. Temperature profiles of the air stream recorded by IR camera at different position of the curtain along the textile diffuser with perforations $\phi 10 \mathrm{~mm}$, (row $A$ is closest to the air flow entrance to the textile duct, row $E$ is at the opposite side of the diffuser duct) 
Table 1. Temperature in spots on thermograms from figure 6.

\begin{tabular}{|c|c|c|c|c|c|c|c|c|c|c|c|}
\hline spot & $\begin{array}{c}\mathrm{SP} 01 \\
{\left[{ }^{\circ} \mathrm{C}\right]}\end{array}$ & $\begin{array}{c}\mathrm{SP0} 2 \\
{\left[{ }^{\circ} \mathrm{C}\right]}\end{array}$ & $\begin{array}{c}\mathrm{SP} 03 \\
{\left[{ }^{\circ} \mathrm{C}\right]}\end{array}$ & $\begin{array}{c}\mathrm{SP} 04 \\
{\left[{ }^{\circ} \mathrm{C}\right]}\end{array}$ & $\begin{array}{c}\mathrm{SP} 05 \\
{\left[{ }^{\circ} \mathrm{C}\right]}\end{array}$ & $\begin{array}{c}\mathrm{SP} 06 \\
{\left[{ }^{\circ} \mathrm{C}\right]}\end{array}$ & $\begin{array}{c}\mathrm{SP} 07 \\
{\left[{ }^{\circ} \mathrm{C}\right]}\end{array}$ & $\begin{array}{c}\mathrm{SP} 08 \\
{\left[{ }^{\circ} \mathrm{C}\right]}\end{array}$ & $\begin{array}{c}\mathrm{SP} 09 \\
{\left[{ }^{\circ} \mathrm{C}\right]}\end{array}$ & $\begin{array}{c}\mathrm{SP} 10 \\
{\left[{ }^{\circ} \mathrm{C}\right]}\end{array}$ & $\begin{array}{c}\mathrm{SP} 11 \\
{\left[{ }^{\circ} \mathrm{C}\right]}\end{array}$ \\
\hline $\begin{array}{c}\text { Row } \\
\text { A }\end{array}$ & 27,6 & 27,7 & 27,2 & 26,7 & 26,5 & 27,1 & 27,2 & 26,7 & 26,8 & 26,7 & 26,6 \\
\hline $\begin{array}{c}\text { Row } \\
\text { B }\end{array}$ & 28,3 & 27,9 & 27,5 & 27,1 & 26,9 & 27,7 & 27,5 & 27,2 & 27,3 & 27,1 & 27,0 \\
\hline $\begin{array}{c}\text { Row } \\
\mathrm{C}\end{array}$ & 27,1 & 27,3 & 27,0 & 26,6 & 26,2 & 27,2 & 27,0 & 26,6 & 25,8 & 26,2 & 26,1 \\
\hline $\begin{array}{c}\text { Row } \\
\mathrm{D}\end{array}$ & 26,6 & 27,2 & 26,9 & 26,4 & 26,0 & 26,6 & 26,8 & 26,5 & 25,2 & 25,7 & 25,8 \\
\hline $\begin{array}{c}\text { Row } \\
\mathrm{E}\end{array}$ & 25,6 & 26,1 & 25,9 & 25,6 & 25,1 & 25,5 & 25,8 & 25,5 & 24,6 & 24,6 & 25,1 \\
\hline
\end{tabular}

a)

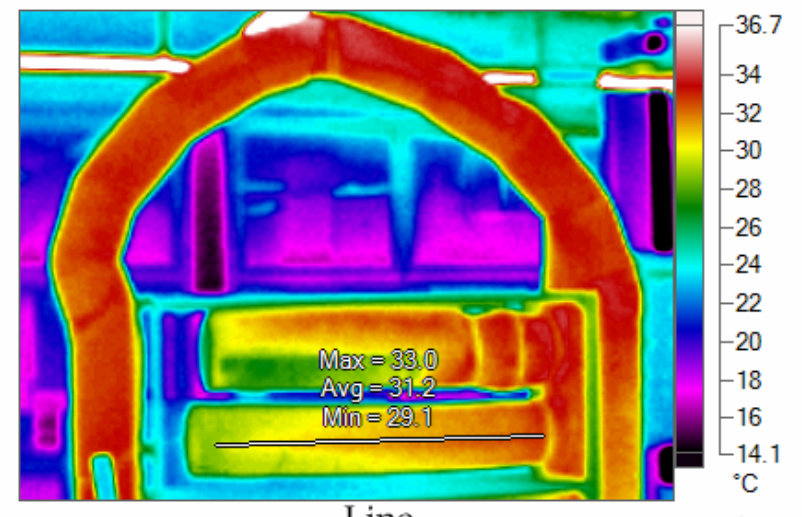

c)

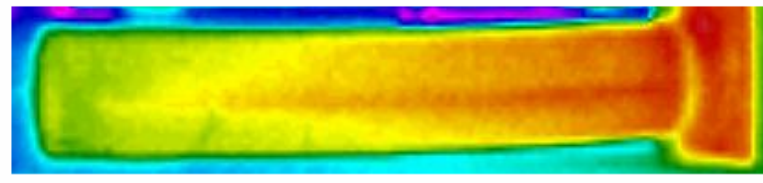

b)

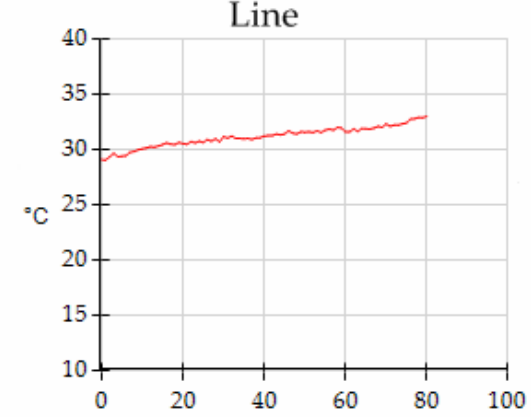

Fig. 7. Thermograms of the textile diffuser with all parts in operation at heating regime, temperature distribution along the lower duct with perforations $(\phi 10 \mathrm{~mm})$

Based on the recorded temperature and velocity profiles, the following empirical correlations were developed for different volume flows and $\Delta t$

$$
\begin{aligned}
& \mathrm{v}=\mathrm{A} x^{4}-\mathrm{B} x^{3}+\mathrm{C} x^{2}-\mathrm{D} x+\mathrm{E} \\
& t=\mathrm{F} x^{2}-\mathrm{G} x+\mathrm{H}
\end{aligned}
$$

where $v(\mathrm{~m} / \mathrm{s})$ is the velocity, $t\left({ }^{\circ} \mathrm{C}\right)$ is the temperature, $x(\mathrm{~m})$ is the distance from the diffuser in the air stream direction, $A, B, C, D, E$ are polynomial coefficients given in tables 2 and 3 . 
Table 2. Polynomial coefficients (equation 1) for different volume flows*

\begin{tabular}{|l|c|c|c|c|c|}
\hline & $\mathrm{A}$ & $\mathrm{B}$ & $\mathrm{C}$ & $\mathrm{D}$ & $\mathrm{E}$ \\
\hline $\begin{array}{l}\text { Isothermal flow } \\
V=417,3 \mathrm{~m}^{3} / \mathrm{h}\end{array}$ & 0,0007 & 0,025 & 0,3234 & 1,7706 & 4,2674 \\
\hline $\begin{array}{l}\text { Isothermal flow } \\
V=470,5 \mathrm{~m}^{3} / \mathrm{h}\end{array}$ & 0,001 & 0,0343 & 0,4074 & 2,0548 & 4,4978 \\
\hline $\begin{array}{l}\text { Non-isothermal flow } \\
\Delta t=5,8^{\circ} \mathrm{C} \\
V=417,3 \mathrm{~m}^{3} / \mathrm{h}\end{array}$ & 0,0035 & 0,0918 & 0,845 & 3,3077 & 5,382 \\
\hline $\begin{array}{l}\text { Non-isothermal flow } \\
\begin{array}{l}\Delta t=5,8^{\circ} \mathrm{C} \\
V=470,5 \mathrm{~m}^{3} / \mathrm{h}\end{array}\end{array}$ & 0,0025 & 0,0643 & 0,5806 & 2,2554 & 4,1062 \\
\hline $\begin{array}{l}\text { Non-isothermal flow } \\
\Delta t=4,1^{\circ} \mathrm{C} \\
V=417,3 \mathrm{~m}^{3} / \mathrm{h}\end{array}$ & 0,0073 & 0,1721 & 1,4212 & 5,0764 & 8,5612 \\
\hline $\begin{array}{l}\text { Non-isothermal flow } \\
\Delta t=4,1^{\circ} \mathrm{C} \\
V=470,5 \mathrm{~m}^{3} / \mathrm{h}\end{array}$ & 0,006 & 0,1552 & 1,4077 & 5,4033 & 9,3387 \\
\hline
\end{tabular}

*all volume flow rates are referred to $1 \mathrm{~m}$ of the diffuser length

Table 3. Polynomial coefficients (equation 2) for different volume flows*

\begin{tabular}{|c|c|c|c|}
\hline & $F$ & G & $\mathrm{H}$ \\
\hline $\begin{array}{l}\text { Non-isothermal flow } \\
\Delta t=5,8{ }^{\circ} \mathrm{C} \\
V=417,3 \mathrm{~m}^{3} / \mathrm{h}\end{array}$ & 0,133 & 0,4113 & 27,285 \\
\hline $\begin{array}{l}\text { Non-isothermal flow } \\
\Delta t=5,8^{\circ} \mathrm{C} \\
V=470,5 \mathrm{~m}^{3} / \mathrm{h}\end{array}$ & 0,1391 & 0,4609 & 27,539 \\
\hline $\begin{array}{l}\text { Non-isothermal flow } \\
\Delta t=4,1{ }^{\circ} \mathrm{C} \\
V=417,3 \mathrm{~m}^{3} / \mathrm{h}\end{array}$ & 0,1069 & 0,378 & 27,22 \\
\hline $\begin{array}{l}\text { Non-isothermal flow } \\
\Delta t=4,1^{\circ} \mathrm{C} \\
V=470,5 \mathrm{~m}^{3} / \mathrm{h}\end{array}$ & 0,1031 & 0,3527 & 27,251 \\
\hline
\end{tabular}

*all volume flow rates are referred to $1 \mathrm{~m}$ of the diffuser length

\section{DISCUSSION AND CONCLUSIONS}

The velocity and temperature profile measurements in air stream of the textile air diffuser have been carried out. It can be seen from figure 3 that the highest velocities are present in mid part of the diffuser. These velocities drop below $v=0,5 \mathrm{~m} / \mathrm{s}$ at a relatively large distance from the diffuser $(x=5 \mathrm{~m})$. The velocities at the side parts of diffuser duct (rows $A$ and D) are remarkably lower. The same applies for the upper and lower planes velocities relative to the central plane that includes the perforations [2]. The temperatures recorded by thermocouples and IR camera are in a relatively good agreement (average difference $0,5^{\circ} \mathrm{C}$, figure 5). Figures 4 and 6 indicate higher temperatures in the air stream closer to the air flow entrance to the diffuser duct. This non-uniformity in temperature distribution along the diffuser duct is also visible from the thermogram on figure 7. Thermograms on Fig. 6 show relatively high air stream spread angle and good induction with the surrounding air.

The presented results confirm suitability of textile duct for delivering larger quantities of conditioned air directly into occupied zone at low velocities. A further research will be directed to the textile diffusers with micro perforations. 


\section{REFERENCES}

[1] Fontanini A., Olsen M. G., Ganapathysubramanian B., "Thermal comparison between ceiling diffusers and fabric ductwork diffusers for green buildings", ASHRAE Handbook - Fundamentals, ASHRAE Atlanta, 1997.

[2] Burek V., "Analysis of the air stream from the textile air diffuser", MSc. thesis, University of Zagreb, Zagreb , 2012.

[3] MASTERCLASS - AIR CONDITIONING TECHNOLOGY, Textile Based Air Distribution, 2011.

[4] Prihoda - Technical data „Textile air diffusers“, 2011.

[5] Andrassy M., Boras I. and Svaic S.: "Basics of thermography and applications", Kigen d.o.o., Zagreb, 2008.

[6] Gioodfelow H., Tahti E.: "Industrial Ventilation Design Guidebook", Academic Press, San Diego, California, 2001.

[7] Awbi H.B.: "Ventilation of Buildings", Spon Press, Taylor\&Francise Library, 2005. 